\title{
Nickel/Metal Hydride Cells Using an Alkaline Polymer Gel Electrolyte Based on Potassium Salt of Crosslinked Poly(acrylic acid)
}

\author{
Chiaki IWAKURA, ${ }^{*}$ Naoji FURUKAWA, Toshiyuki OHNISHI, \\ Kouichi SAKAMOTO, Shinji NOHARA, and Hiroshi INOUE
}

\begin{abstract}
Department of Applied Chemistry, Graduate School of Engineering, Osaka Prefecture University (1-1 Gakuen-cho, Sakai, Osaka 599-8531, Japan)
\end{abstract}

Received December 11, 2000 ; Accepted May 5, 2001

\begin{abstract}
Alkaline polymer gel electrolyte with high ionic conductivity was prepared from potassium salt of crosslinked poly (acrylic acid) and KOH aqueous solution in order to investigate the applicability of the polymer gel electrolyte to alkaline secondary batteries such as nickel/metal hydride $(\mathrm{Ni} / \mathrm{MH})$ battery. An experimental $\mathrm{Ni} / \mathrm{MH}$ cell was assembled using the polymer gel electrolyte and its charge-discharge and capacity retention characteristics were tested. A similar type of $\mathrm{Ni} / \mathrm{MH}$ cell was also assembled using a $6 \mathrm{M} \mathrm{KOH}$ aqueous solution for comparison. The former cell was found to exhibit rather better charge-discharge and capacity retention characteristics than the latter cell.
\end{abstract}

Key Words : Polymer Gel Electrolyte, Ionic Conductivity, Ni/MH Battery, Charge-discharge Characteristics

\section{Introduction}

There has been a strong demand for rechargeable batteries to use a solid or gel electrolyte instead of a liquid electrolyte. ${ }^{1-4)} \mathrm{Nickel} /$ metal hydride $(\mathrm{Ni} / \mathrm{MH})$ battery with a solid or gel electrolyte would be attractive especially in terms of its reliability, safety, designing and processibility. Properties such as electrode/electrolyte interface, ionic conductivity, electrochemical stability, thermal stability and mechanical strength of the electrolyte would become important factors to realize all-solid-state $\mathrm{Ni} / \mathrm{MH}$ and related batteries. However, there have been only a few reports on a solid or gel electrolyte with high ionic conductivity for use in the $\mathrm{Ni} / \mathrm{MH}$ and related batteries.

Mohri et al. ${ }^{5,6)}$ have first reported $\mathrm{Ni} / \mathrm{MH}$ related batteries using $\mathrm{Sb}_{2} \mathrm{O}_{5} \cdot \mathrm{xH}_{2} \mathrm{O}$ as a solid electrolyte; e.g. TiNi : $\mathrm{MmH}_{\mathrm{x}}(\mathrm{Mm}=1 \mathrm{wt} \%) / \mathrm{Sb}_{2} \mathrm{O}_{5} \cdot \mathrm{xH}_{2} \mathrm{O} / \mathrm{MnO}_{2}$. Kuriyama et $a l .{ }^{7-9)}$ have investigated $\mathrm{Ni} / \mathrm{MH}$ and related batteries using tetramethylammonium hydroxide pentahydrate, $\left(\mathrm{CH}_{3}\right)_{4} \mathrm{NOH} \cdot 5 \mathrm{H}_{2} \mathrm{O}$ as a solid electrolyte with proton conductivity ; e.g. $\mathrm{LaNi}_{2.5} \mathrm{CO}_{2.4} \mathrm{Al}_{0.1} \mathrm{H}_{\mathrm{x}} /\left(\mathrm{CH}_{3}\right)_{4}$ $\mathrm{NOH} \cdot 5 \mathrm{H}_{2} \mathrm{O} / \mathrm{NiOOH}$ or $\mathrm{MnO}_{2}$. Very recently $\mathrm{Ni} / \mathrm{MH}$ batteries with an alkaline solid polymer electrolyte based on poly(ethylene oxide)( $\mathrm{PEO}$ ), $\mathrm{KOH}$ and water have been reported by Vassal et al. ${ }^{10,11)}$; e.g. $\mathrm{LaMmNi}_{3.55} \mathrm{Al}_{0.3} \mathrm{Mn}_{0.4}$ $\mathrm{Co}_{0.75} \mathrm{H}_{\mathrm{x}} / \mathrm{PEO}-\mathrm{KOH}-\mathrm{H}_{2} \mathrm{O} / \mathrm{NiOOH}$. These batteries showed long charge-discharge cycle life but rather small current density to be drawn because of low ionic conductivity of the electrolytes, as compared with aqueous electrolytebased $\mathrm{Ni} / \mathrm{MH}$ batteries.

Poly (acrylic acid) is a well-known polymer that has a high water-absorbing capacity, a high water-holding capacity, a high gel strength and a relatively low cost. So, in this work, alkaline polymer gel electrolyte was prepared from potassium salt of crosslinked poly(acrylic acid) and $\mathrm{KOH}$ aqueous solution in order to investigate the applicability of the polymer gel electrolyte to alkaline secondary batteries such as $\mathrm{Ni} / \mathrm{MH}$ battery. The simple experimental $\mathrm{Ni} / \mathrm{MH}$ cell for a preliminary investigation was assembled using the polymer gel electrolyte and its charge-discharge and capacity retention characteristics were tested under several conditions. The main purpose of this preliminary work was to compare roughly the electrochemical characteristics between the polymer gel electrolyte-based cell and the $\mathrm{KOH}$ aqueous solutionbased cell under the same conditions.

\section{Experimental}

\section{1 Preparation of polymer gel electrolyte}

The alkaline polymer gel electrolyte was prepared according to the following steps. One gram of potassium salt of poly(acrylic acid) having lightly crosslinked network (Aldrich, \#43532-5) was added to $0.01 \mathrm{dm}^{3}$ of $\mathrm{KOH}$ aqueous solution in concentration from 2 to $20 \mathrm{M}$ (M = mol $\mathrm{dm}^{-3}$ ) with stirring in a beaker at room temperature. The resulting initial gel was allowed to stand for over 70 $\mathrm{h}$ at $25^{\circ} \mathrm{C}$ in an airtight glass vessel to avoid water evaporation and absorption of carbon dioxide. After the gel formation was completed, air bubbles in the gel were removed under vacuum. The resulting transparent gel was stored at $25^{\circ} \mathrm{C}$.

\section{2 Preparation of negative electrode}

An ingot of $\mathrm{MmNi}_{3.6} \mathrm{Mn}_{0.4} \mathrm{Al}_{0.3} \mathrm{Co}_{0.7}$ alloy was prepared by arc melting under an argon atmosphere in a watercooled copper crucible. The alloy was pulverized mechanically being passed through graded sieves to obtain alloy particles in the range of 106 to $125 \mu \mathrm{m}$.

Roll-compacted metal hydride electrodes were prepared according to the following steps. The alloy powder $(95 \mathrm{wt} \%)$, acetylene black (4 wt\%) and PTFE powder (1 
wt $\%$ ) were mixed thoroughly with using $0.001 \mathrm{dm}^{3}$ of ethanol as a solvent, followed by roll-pressing the paste to form its sheet on a flat plate. The resulting disc of the sheet (thickness : $c a .200 \mu \mathrm{m}$, surface area $: 0.58 \mathrm{~cm}^{2}$ ) containing $c a .30 \mathrm{mg}$ of the alloy was placed onto a porous nickel substrate followed by pressing it at $3 \times 10^{7} \mathrm{~kg}$ $\mathrm{m}^{-2}$ for $5 \mathrm{~min}$ to prepare paste-type negative electrode.

\section{3 Cell assembly}

Experimental cell assembly for the polymer gel electrolyte-based $\mathrm{Ni} / \mathrm{MH}$ cell is shown in Fig. 1. In this work, the simple type cell was used to obtain basic electrochemical data. A similar type of $\mathrm{Ni} / \mathrm{MH}$ cell was also assembled using a $6 \mathrm{M} \mathrm{KOH}$ aqueous solution as an electrolyte for comparison. The negative and positive electrodes were activated in a $6 \mathrm{M} \mathrm{KOH}$ aqueous solution in a glass beaker at $30^{\circ} \mathrm{C}$ prior to the setting of the electrodes in the test cell. The paste-type negative electrode $\left(\mathrm{MmNi}_{3.6} \mathrm{Mn}_{0.4} \mathrm{Al}_{0.3} \mathrm{Co}_{0.7} \mathrm{H}_{\mathrm{x}}\right)$, a disc of polymer gel electrolyte $\left(3 \mathrm{~mm}\right.$ thick, $\left.1.54 \mathrm{~cm}^{2}\right)$, positive electrode $(\mathrm{NiOOH})$ used in commercial batteries and a polypropylene sheet with a circular hole $\left(3 \mathrm{~mm}\right.$ thick, $\left.1.54 \mathrm{~cm}^{2}\right)$ as a spacer were stacked alternately as shown in the figure. No separator was used in this cell for simplification. The polymer gel electrolyte consisted of $7 \mathrm{wt} \%$ potassium salt of crosslinked poly(acrylic acid), $23 \mathrm{wt} \% \mathrm{KOH}$ and $70 \mathrm{wt} \% \mathrm{H}_{2} \mathrm{O}$ was used as the electrolyte for the test battery. The battery was deaerated under vacuum, and then stored in an argon atmosphere taking care of avoiding water evaporation. Total thickness of the battery in this work was about $5 \mathrm{~mm}$.

\section{4 Electrochemical measurements}

In charge-discharge cycle tests, the negative electrode was charged at $50 \mathrm{~mA} \mathrm{~g} \mathrm{~g}^{-1}$ for $4 \mathrm{~h}\left(200 \mathrm{mAh}^{-1}\right)$ and discharged at various currents to $0.8 \mathrm{~V}$ of the cut-off cell voltage. After each charging, the circuit was kept open for $10 \mathrm{~min}$. Charge-discharge cycle tests were performed using galvanostatic charge-discharge unit (Hokuto Denko $\mathrm{HJ}-101 \mathrm{SN}$ 6). Capacity retention was evaluated as a function of storage time at the charge and discharge currents of $50 \mathrm{~mA} \mathrm{~g}^{-1}$.

The conductivity of the polymer gel electrolyte was measured by AC impedance spectroscopy between $10 \mathrm{~Hz}$ and $10 \mathrm{kHz}$. A small glass beaker $\left(5 \mathrm{~cm}^{3}\right)$ with two plati-

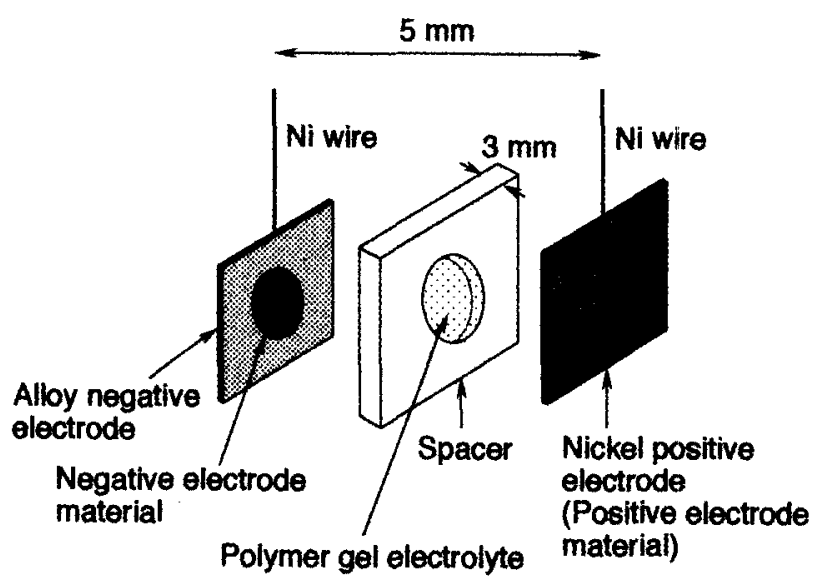

Fig. 1 Experimental cell assembly for the polymer gel electrolyte-based $\mathrm{Ni} / \mathrm{MH}$ cell. nized platinum electrodes placed in $1 \mathrm{~cm}$ distance was used for the conductivity cell. Voltammetric study was carried out to examine the electrochemical stability of the polymer gel electrolyte using a Pt working electrode.

\section{Results and Discussion}

3. 1 Electrochemical characteristics of polymer gel electrolyte

Figure 2 shows the conductivity of polymer gel electrolytes and $\mathrm{KOH}$ aqueous solutions at $25^{\circ} \mathrm{C}$. It can be seen from this figure that the conductivity of the polymer gel electrolytes is very high because of its high content of a $6 \mathrm{M} \mathrm{KOH}$ aqueous solution, compared with the PEO$\mathrm{KOH}-\mathrm{H}_{2} \mathrm{O}$ (typically 60-30-10 wt \%) electrolyte reported by Vassal et al. ${ }^{10,11)}$ The conductive behavior of the polymer gel electrolytes bears a striking resemblance to $\mathrm{KOH}$ aqueous solutions. Maximal conductivity can be seen at intermediate $\mathrm{KOH}$ concentration in both electrolytes. This phenomenon is qualitatively interpreted as follows ; at low $\mathrm{KOH}$ concentrations, conductivity decreases due to a low number of charge carriers, whereas at high $\mathrm{KOH}$ concentrations, conductivity decreases due to restriction of ionic mobility.

Figure 3 shows Arrhenius plots of the conductivity for the polymer gel electrolyte and a $6 \mathrm{M} \mathrm{KOH}$ aqueous solution. An approximately linear dependency can be seen from this figure over the temperature range of -40 to $80^{\circ} \mathrm{C}$. Activation energies for ionic conduction in the polymer gel electrolyte and a $6 \mathrm{M} \mathrm{KOH}$ aqueous solution were calculated to be 13.7 and $13.4 \mathrm{~kJ} \mathrm{~mol}^{-1}$, respectively. The ion conduction mechanism of both electrolytes may be quite similar over the entire concentration of $\mathrm{KOH}$ and the temperature range measured in this work. No deterioration or decomposition of the polymer gel was found even in concentrated alkaline media.

The electrochemical behavior of the polymer gel electrolyte was examined by cyclic voltammetry using a smooth platinum electrode. The experiment was performed in the polymer gel electrolyte and a $6 \mathrm{M} \mathrm{KOH}$ aqueous solution under argon atmosphere at a scan rate of $100 \mathrm{mV} \mathrm{s}^{-1}$. As can be seen from Fig. 4, there are wellknown reaction currents in the $\mathrm{KOH}$ aqueous solution in

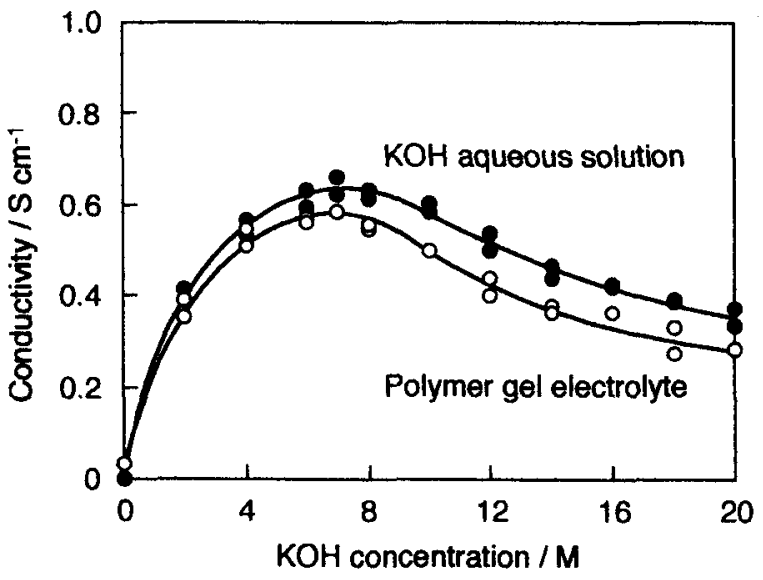

Fig. 2 Effect of the $\mathrm{KOH}$ concentration on the conductivity of polymer gel electrolytes and $\mathrm{KOH}$ aqueous solutions at $25^{\circ} \mathrm{C}$. 


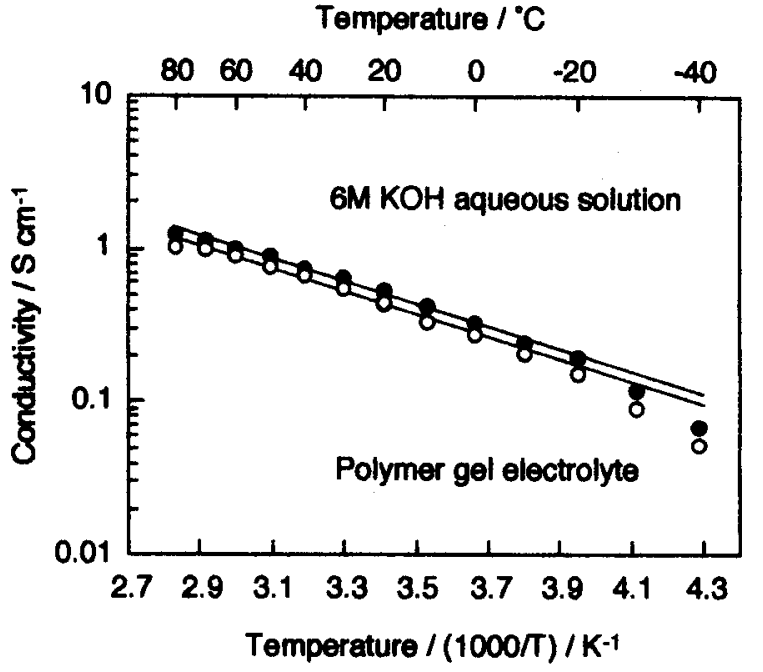

Fig. 3 Arrhenius plots of the conductivity for the polymer gel electrolyte and a $6 \mathrm{M} \mathrm{KOH}$ aqueous solution.

the potential ranges $-1.0 \sim+0.6 \mathrm{~V}$ vs. $\mathrm{Hg} / \mathrm{HgO}:$ formation of adsorbed hydrogen, oxidation of the adsorbed hydrogen, formation of adsorbed oxygen or platinum oxide layer, reduction of the oxide. Similar reaction currents have been also found in the cyclic voltammogram for the polymer gel electrolyte, however, no significant currents for extra reactions were seen in the voltammogram. From these results, it has been found that no decomposition of the gel electrolyte of potassium salt of crosslinked poly (acrylic acid) occurred in the potential ranges $(-1.0$ $\sim+0.5 \mathrm{~V}$ vs. $\mathrm{Hg} / \mathrm{HgO}$ ) for charge and discharge of the $\mathrm{Ni} / \mathrm{MH}$ cell.

Since this polymer gel electrolyte have high conductivity and rather wide potential window, it could become a potential candidate as an electrolyte of alkaline secondary batteries such as a Ni/MH battery.

\section{2 Charge-discharge characteristics}

Figure 5 shows typical charge-discharge curves (at 1st, 10 th and 50 th cycles) of the $\mathrm{Ni} / \mathrm{MH}$ cells with the polymer gel and a $6 \mathrm{M} \mathrm{KOH}$ aqueous solution at $25^{\circ} \mathrm{C}$. Welldefined charge and discharge curves were obtained in either case. A plateau of the cell voltage is seen in the discharge curves ranging from 1.3 to $1.1 \mathrm{~V}$. At the first

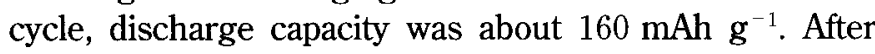
the second cycle, stationary discharge capacity of $c a$. $170-180 \mathrm{mAh} \mathrm{g}^{-1}$ was obtained which corresponds to $c a$. $85-90 \%$ of the charged quantity of electricity $(200 \mathrm{mAh}$ $\mathrm{g}^{-1}$ ) of the negative electrode.

The voltage at the last stage of discharge for the $\mathrm{Ni}$ / $\mathrm{MH}$ cell with the polymer gel electrolyte is rather high, compared to the $\mathrm{Ni} / \mathrm{MH}$ cell with a $6 \mathrm{M} \mathrm{KOH}$ aqueous solution. In the $\mathrm{Ni} / \mathrm{MH}$ cell of this work, the polymer gel electrolyte and a $6 \mathrm{M} \mathrm{KOH}$ aqueous solution were $3 \mathrm{~mm}$ thick and no separator was used. As difference of the conductivity between both electrolytes was so small ( $c a$. $0.6 \mathrm{~S} \mathrm{~cm} \mathrm{~cm}^{-1}$ in Fig. 3), difference of the voltage drops across through the gel and aqueous electrolytes of $3 \mathrm{~mm}$ in thickness can be neglected. Although active materials were impregnated in the foamed nickel substrate under high pressure, the active materials might be partially re-

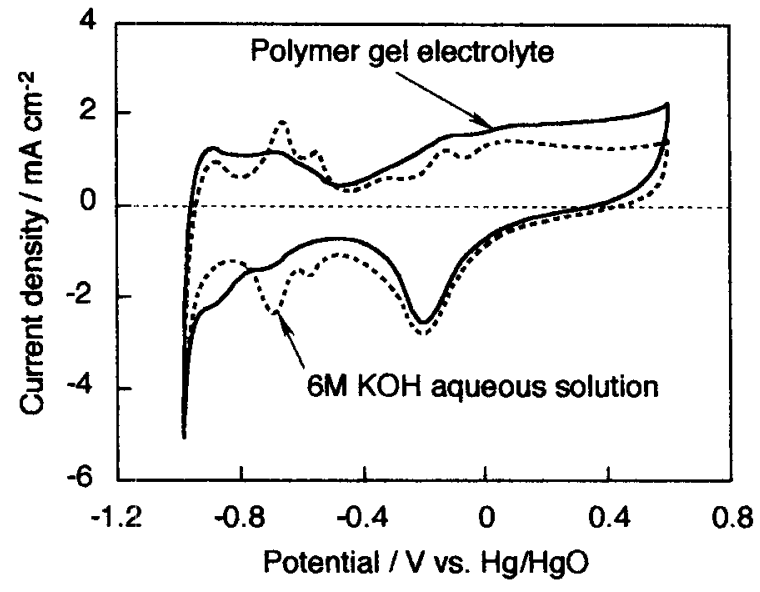

Fig. 4 Cyclic voltammograms of Pt electrode in the polymer gel electrolyte and a $6 \mathrm{M} \mathrm{KOH}$ aqueous solution at $25^{\circ} \mathrm{C}$. Scan rate $: 100 \mathrm{mV} \mathrm{s}^{-1}$.
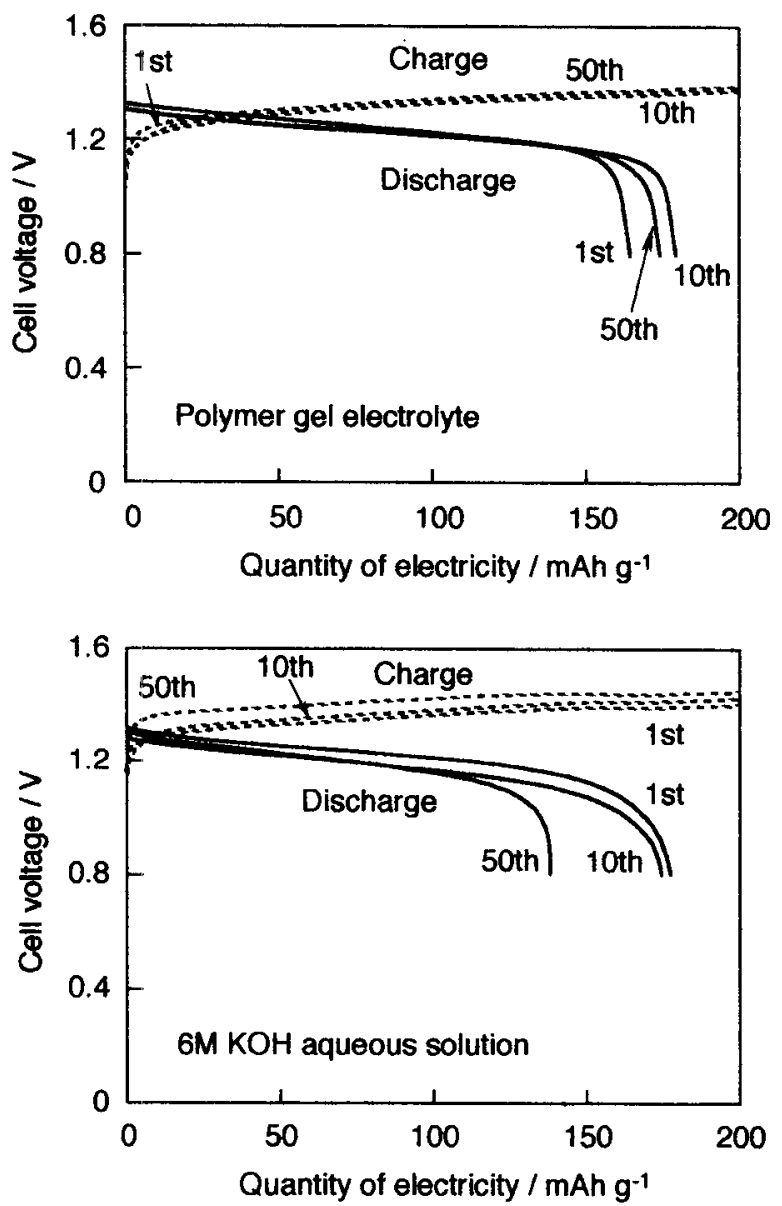

Fig. 5 Typical charge-discharge curves (at 1st, 10th and 50th cycles) of the $\mathrm{Ni} / \mathrm{MH}$ cells with the polymer gel electrolyte and a $6 \mathrm{M} \mathrm{KOH}$ aqueous solution at $25^{\circ} \mathrm{C}$. Quantity of electricity is expressed by the charge passed per unit weight of the alloy used in negative electrode.

leased from the electrode during the charge-discharge process. But, as a whole, charge-discharge characteristics of both $\mathrm{Ni} / \mathrm{MH}$ cells are quite similar to each other.

Relationships between charged quantity of electricity and discharge capacity are shown in Fig. 6 for the $\mathrm{Ni} /$ MH cells with the polymer gel electrolyte and a $6 \mathrm{M}$ 
$\mathrm{KOH}$ aqueous solution. The discharge capacity was $85 \sim$ $90 \%$ of the charged quantity of electricity. The electrochemical reaction of potassium salt of crosslinked poly (acrylic acid) seemed not to occur during charging process (Fig. 4). Decrease of discharge capacity from the nominal capacity might be caused by hydrogen release from the negative electrode because the experimental cell was of an open type.

Figure 7 shows discharge capacities at $25^{\circ} \mathrm{C}$ as a function of cycle number for the $\mathrm{Ni} / \mathrm{MH}$ cells with the polymer gel electrolyte and a $6 \mathrm{M} \mathrm{KOH}$ aqueous solution. As can be seen from this figure, cycle life of the cell with the polymer gel electrolyte was prolonged keeping discharge capacity of over $85 \%$ even at 50 th cycle. The discharge capacity was about $70 \%$ of charged quantity of electricity at 300 th cycle. Under the present conditions there may be no problems in the electrode/electrolyte interface, and then charge and discharge reactions might proceed smoothly. These were resulted from high waterholding capacity of potassium salt of crosslinked poly (acrylic acid). The polymer gel electrolyte might hold enough water for smooth progress of the chargedischarge reactions at the positive and negative electrodes. The polymer gel electrolyte used in this work was found to be so stable during charge-discharge cycling in a concentrated $\mathrm{KOH}$ aqueous solution. It had a strong adhesive force to the electrode materials, and thus contact discontinuity between electrode and gel electrolyte did not occur during the cycle test. Another type of negative electrode, which was covered with porous nickel plate to prevent degradation of alloy powder from the porous nickel substrate during the cycle test, was also used in the case of the $\mathrm{Ni} / \mathrm{MH}$ cell with a $6 \mathrm{M}$ $\mathrm{KOH}$ aqueous solution. It was found from Fig. 7 that the $\mathrm{Ni} / \mathrm{MH}$ cell using the negative electrode covered with porous nickel plate showed better cycle performance than the cell without porous nickel plate in a $6 \mathrm{M} \mathrm{KOH}$ aqueous solution.

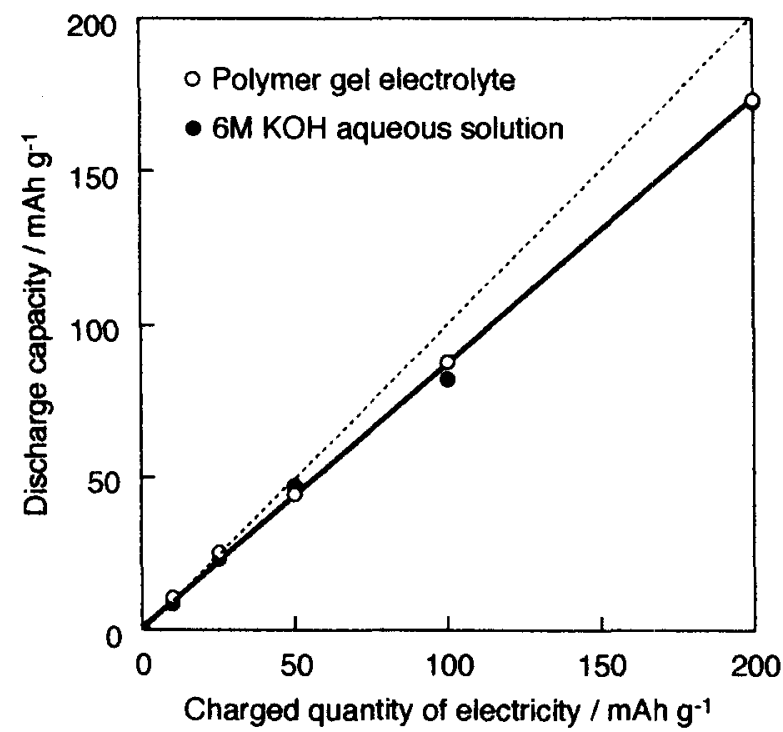

Fig. 6 Relationship between charged quantity of electricity and discharge capacity for the $\mathrm{Ni} / \mathrm{MH}$ cells with the polymer gel electrolyte and a $6 \mathrm{M} \mathrm{KOH}$ aqueous solution at $25^{\circ} \mathrm{C}$.
Figure 8 shows capacity retention obtained from the storage test for twelve days of the $\mathrm{Ni} / \mathrm{MH}$ cells with the polymer gel electrolyte and a $6 \mathrm{M} \mathrm{KOH}$ aqueous solution at $25^{\circ} \mathrm{C}$. The capacity retention of these experimental cells is lower than that of the commercial $\mathrm{Ni} / \mathrm{MH}$ batteries. This is probably because these experimental cells were of an open type and assembled without using a separator for simplification. However, it is clear from this figure that the capacity retention of the $\mathrm{Ni} / \mathrm{MH}$ cell with the polymer gel electrolyte was much higher than that of the $\mathrm{Ni} / \mathrm{MH}$ cell with a $6 \mathrm{M} \mathrm{KOH}$ aqueous solution. Table 1 shows the surface composition of alloys in negative electrodes stored for eight days (Fig. 8) in the polymer gel electrolyte and a $6 \mathrm{M} \mathrm{KOH}$ aqueous solution. The composition of the alloys was determined by EPMA. No significant change was observed for the contents of $\mathrm{Mm}$, $\mathrm{Ni}$ and $\mathrm{Co}_{\mathrm{O}}$ of the alloys before and after the storage test. However, the contents of $\mathrm{Mn}$ and $\mathrm{Al}$ decreased for the alloys after the storage test in the polymer gel electrolyte and a $6 \mathrm{M} \mathrm{KOH}$ aqueous solution. This result is attributed to the dissolution of those metals in the electrolytes during storage of the cells, affecting the discharge capacity of the cells. It should be noted that the dissolution

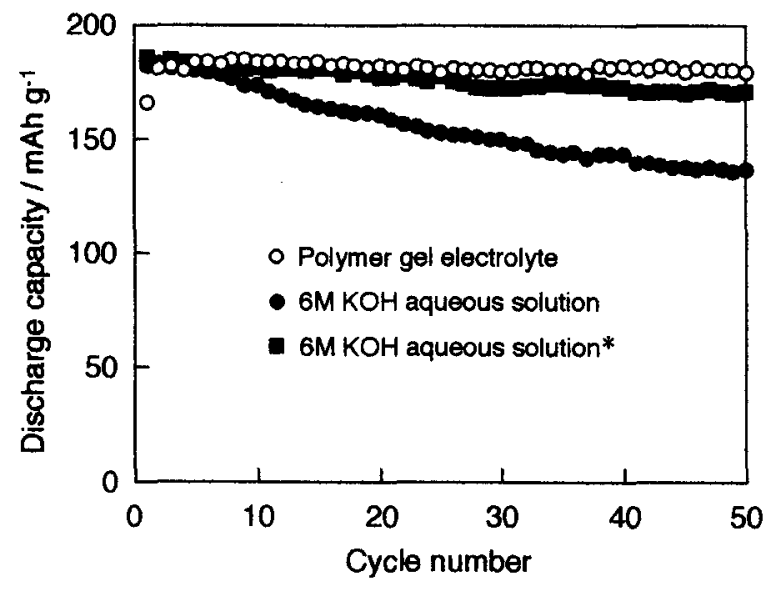

Fig. 7 Discharge capacities at $25^{\circ} \mathrm{C}$ as a function of cycle number for the $\mathrm{Ni} / \mathrm{MH}$ cells with the polymer gel electrolyte and a $6 \mathrm{M} \mathrm{KOH}$ aqueous solution. *negative electrode covered with porous $\mathrm{Ni}$ plate.

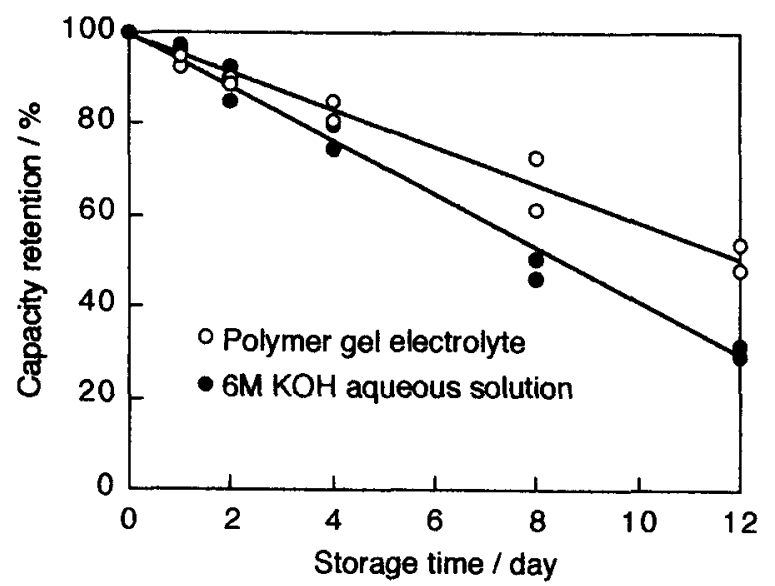

Fig. 8 Capacity retention characteristics of the $\mathrm{Ni} / \mathrm{MH}$ cells with the polymer gel electrolyte and a $6 \mathrm{M} \mathrm{KOH}$ aqueous solution at $25^{\circ} \mathrm{C}$. 
Table 1 Surface composition of alloys in negative electrodes stored for eight days in the polymer gel electrolyte and a $6 \mathrm{M} \mathrm{KOH}$ aqueous solution.

\begin{tabular}{lccccc}
\hline \multirow{2}{*}{ Negative electrode } & \multicolumn{5}{c}{$\begin{array}{c}\text { atom\% } \\
\text { (M/Mm ratio) }\end{array}$} \\
\cline { 2 - 6 } & $\mathrm{Mm}$ & $\mathrm{Ni}$ & $\mathrm{Mn}$ & $\mathrm{Al}$ & $\mathrm{Co}$ \\
\hline As prepared & 18.6 & 60.8 & 5.3 & 4.0 & 11.2 \\
& $(1.00)$ & $(3.27)$ & $(0.28)$ & $(0.22)$ & $(0.60)$ \\
Stored in the polymer & 18.2 & 61.6 & 5.1 & 2.8 & 11.2 \\
gel electrolyte & $(1.00)$ & $(3.38)$ & $(0.28)$ & $(0.16)$ & $(0.60)$ \\
Stored in a 6 M KOH & 18.8 & 62.0 & 4.6 & 2.3 & 11.5 \\
aqueous solution & $(1.00)$ & $(3.30)$ & $(0.24)$ & $(0.12)$ & $(0.61)$ \\
\hline
\end{tabular}

rates of those elements are larger in a $6 \mathrm{M} \mathrm{KOH}$ aqueous solution than the polymer gel electrolyte. This is probably due to the low solubility of alloy constituents in the polymer gel electrolyte. It seemed that inhibition of the dissolution of those metals resulted in high capacity retention of the $\mathrm{Ni} / \mathrm{MH}$ cell with the polymer gel electrolyte. Work along this line is in progress.

\section{Conclusion}

The polymer gel electrolyte prepared from potassium salt of crosslinked poly (acrylic acid) and a $\mathrm{KOH}$ aqueous solution was found to have high ionic conductivity almost comparable to the $\mathrm{KOH}$ aqueous solution over the wide ranges of $\mathrm{KOH}$ concentration and temperature. The polymer gel electrolyte had enough potential windows for charge and discharge reactions of the $\mathrm{Ni} / \mathrm{MH}$ battery. The experimental $\mathrm{Ni} / \mathrm{MH}$ cell assembled using the polymer gel electrolyte exhibited equivalent or better chargedischarge and capacity retention characteristics at $25^{\circ} \mathrm{C}$, compared with the cell assembled using a $6 \mathrm{M} \mathrm{KOH}$ aqueous solution. The polymer gel electrolyte has found to be stable in concentrated $\mathrm{KOH}$ aqueous solution and acted as an excellent electrolyte to avoid rapid evaporation of water from the gel. The polymer gel electrolyte used in this work therefore seems to have the applicability to alkaline secondary batteries such as a $\mathrm{Ni} / \mathrm{MH}$ battery.

\section{Acknowledgement}

This work was partially supported by a Grant-in-Aid for
Scientific Research on Priority Areas (B) of "Ionics Devices" (No.11229101, No.11229205) and Scientific Research on Priority Areas (A) of "New Protium Function" (No.10148105) from the Ministry of Education, Science, Sports and Culture of Japan.

\section{References}

1) J.-F. Fauvarque, S. Guinot, N. Bouzir, E. Salmon, and I.-F. Penneau, Electrochim. Acta, 40, 2449 (1995).

2) S. Guinot, E. Salmon, J. F. Penneau, and J.-F. Fauvarque, Electrochim. Acta, 43, 1163 (1998).

3) A. M. Grillone, S. Panero, B. A. Retamal, and B. Scrosati, J. Electrochem. Soc., 146, 27 (1999).

4) M. Kono, E. Hayashi, and M. Watanabe, J. Electrochem. Soc., 146, 1626 (1999).

5) M. Mohri, Y. Tajima, H. Tanaka, T. Yoneda, and M. Kasahara, Sharp Tech. J., 34, 97 (1986) (in Japanese).

6) T. Yoneda, S. Satoh, and M. Mohri, Sharp Tech. J., 38, 55 (1987) (in Japanese).

7) N. Kuriyama, T. Sakai, H. Miyamura, A. Kato, and H. Ishikawa, Denki Kagaku (presently Electrochemistry), 58, 89 (1990) (in Japanese).

8) N. Kuriyama, T. Sakai, H. Miyamura, A. Kato, and H. Ishikawa, J. Electrochem. Soc., 137, 355 (1990).

9) N. Kuriyama, T. Sakai, H. Miyamura, A. Kato, and H. Ishikawa, Solid State Ionics, 40/41, 906 (1990).

10) N. Vassal, E. Salmon, and J.-F. Fauvarque, J. Electrochem. Soc., 146, 20 (1999).

11) N. Vassal, E. Salmon, and J.-F. Fauvarque, Electrochim. Acta, 45, 1527 (2000). 